\title{
Nanostructured Ag3PO4 from natural phosphate: High-efficient catalytic reduction of 4-nitrophenol and antibacterial studies.
}

KARIM DÄNOUN ( $\nabla$ k.danoun@mascir.ma )

MAScIR Foundation https://orcid.org/0000-0002-0867-3627

Rida Tabit

Hassan II University of Casablanca

Abdelaziz Laghzizil

Mohammed V University

Mohamed Zahouily

MAScIR Foundation

\section{Research Article}

Keywords: Nanostructured Ag3P04, Natural phosphate, Nitrophenol reduction, Heterogeneous catalyst

Posted Date: March 17th, 2021

DOI: https://doi.org/10.21203/rs.3.rs-296915/v1

License: (9) This work is licensed under a Creative Commons Attribution 4.0 International License. Read Full License 


\section{Abstract}

In this paper, a novel approach was successfully developed for preparing nanostructured $\mathrm{Ag}_{3} \mathrm{PO}_{4}$ using Moroccan phosphate as a source for phosphorus precursor. The as-synthetized nanomaterial was characterized using various techniques. A pure crystalline $\mathrm{Ag}_{3} \mathrm{PO}_{4}$ phase was obtained after drying, exhibiting a mesoporous structure with specific surface area of $35 \mathrm{~m}^{2} \mathrm{~g}^{-1}$. The use of this simple, environmentally friendly, and inexpensive procedure can be useful for the development of nanostructured $\mathrm{Ag}_{3} \mathrm{PO}_{4}$ catalyst with excellent catalytic activity for reduction of 4-nitrophenol to 4-aminophenol in the presence of $\mathrm{NaBH}_{4}$ as reducing agent. Furthermore, the $\mathrm{Ag}_{3} \mathrm{PO}_{4}$ material was also used as an antibacterial agent against Escherichia-coli and Staphylococcus-aureus bacteria.

\section{Introduction}

With industrialization processes and more human activities, the environmental contamination caused by organic pollutants is becoming an overwhelming mystery all over the world [1-2]. The phenolic compounds are considered to be one of the most notorious pollutants generated by industrials sources such as synthetic intermediate in the manufacture of pharmaceuticals, plastics, pigments, dyes, pesticides and fungicidal agents, explosives and industrial solvents [3]. Due to their potential to harm human health and living organisms at low concentrations, these compounds were classified as priority materials by the United States Environmental Protection Agency (USEPA) among the top 114 organic pollutants [4-5]. Among the different phenolic compounds, 4-nitrophenol (4-NP) is one of the most frequently occurring products [6]. However, the 4-aminophenol is one of the most important intermediates in the preparing of several analgesic and antipyretic drugs like paracetamol, acetanilide, and phenacetin [7]. Also, it is utilized as corrosion inhibitor in paints, and anticorrosion-lubricating agent in fuels. Further, 4-aminophenol is used efficiently in the dye industry as a wood stain and a dyeing agent for fur and feathers [8]. In view of the harmful effect of 4-NP and the growing demand for 4-AP, the conversion of 4NP directly to 4-AP via catalytic route becomes greatly desirable. Various metal nanoparticles like as platinum, gold, copper, ruthenium and palladium, are used intensively for the reduction of nitrophenols compounds. All these catalysts are very expensive for industrial use in bulk quantity. To reduce the cost of the catalyst, over the past few years, more attention has been paid to synthesis of silver orthophosphate $\mathrm{Ag}_{3} \mathrm{PO}_{4}[9,12]$. However, low-cost fabrication of well-defined $\mathrm{Ag}_{3} \mathrm{PO}_{4}$ with superior catalytic properties via a simple process remains a great challenge. On the other hand, natural phosphates are an important natural resource in Morocco, which needs to be valorized. They can be employed not only as fertilizers but also, they have been exploited effectively as catalysts in a wide range of organic transformation $[13,15]$. In continuation of our ongoing program to develop an interesting catalyst at low-cost $[\mathbf{1 6 , 2 1 ]}$, we describe in this paper, a novel chemical wet method-based dissolutionprecipitation reactions using Moroccan natural phosphate (NP) as phosphorus precursor to synthesize of the nanostructured $\mathrm{Ag}_{3} \mathrm{PO}_{4}$ as catalyst for the reduction of 4-NP to 4-AP in the presence of sodium borohydride using aqueous phase and its antimicrobial activity against Escherichia coli and Staphylococcus aureus bacteria. To the best of our knowledge, no studies have been performed on 
the development of $\mathrm{Ag}_{3} \mathrm{PO}_{4}$ from natural phosphate and testing its catalytic activity for the reduction of 4-NP to 4-AP, and its antibacterial activity against E. coli and $S$. aureus in aqueous solution.

\section{Experimental Section}

\subsection{Materials}

Silver nitrate $\mathrm{AgNO}_{3}(\geq 99.0 \%)$, Ammonia hydroxide solution $\mathrm{NH}_{4} \mathrm{OH}(28 \%)$, 4-nitrophenol $\left(\mathrm{C}_{6} \mathrm{H}_{5} \mathrm{NO}_{3}\right)$, and Sodium borohydride $\left(\mathrm{NaBH}_{4}\right)$ were purchased from Sigma-Aldrich. All reagents were of analytical grade and used as received. Deionized water was utilized through all the preparation procedures.

\subsection{The preparation of nanostructured $\mathrm{Ag}_{3} \mathrm{PO}_{4}$ catalyst}

The $\mathrm{Ag}_{3} \mathrm{PO}_{4}$ was prepared by a dissolution/precipitation method from a natural phosphate rock coming from the Khouribga region (Morocco). To use this material prior requires initial treatments such as crushing and washing. The fraction of $200-400 \mu \mathrm{m}$ grain size was washed with distilled water several times to remove the soluble matter. The different elemental constituents of this mineral are given in Table 1. Then, the dissolution process was carried out in a round bottom flask of $500 \mathrm{ml}$ capacity at a rate of $200 \mathrm{rpm}$. Firstly, about thirty grams of natural phosphate was dissolved in deionized water acidified by $\mathrm{HNO}_{3}$ acid $(65 \%)$ to $\mathrm{pH} 2$, under continuous stirring at room temperature we obtained $\mathrm{H}_{3} \mathrm{PO}_{4}$ and $\mathrm{Ca}^{2+}$ ions as well as the insoluble matter after solid/liquid separation process by centrifugation. Next, the $\mathrm{Ag}_{3} \mathrm{PO}_{4}$ catalyst was prepared by a simple precipitation method. In a typical synthesis, 1.5 grams of $\mathrm{AgNO}_{3}(8.83 \mathrm{mmol})$ was dissolved in $80 \mathrm{ml}$ deionized water over $10 \mathrm{~min}$, then the ammonia hydroxide solution $28 \%(0.1 \mathrm{M})$ was added with drop by drop under magnetic stirring to above mixture to form a transparent solution. And then, phosphorus precursor prepared previously from natural phosphate were added gradually to the mixture reaction, the resulting precipitate was magnetically stirred at room temperature for one hour. After that, a yellow precipitate of silver phosphate $\mathrm{Ag}_{3} \mathrm{PO}_{4}$ is then obtained by centrifugation and washed several times with deionized water to release any unreacted species such as $\mathrm{Ca}^{2+}$ and $\mathrm{NO}^{3-}$ ions. Finally, the obtained powder $\mathrm{Ag}_{3} \mathrm{PO}_{4}$ was dried in desiccator at $80{ }^{\circ} \mathrm{C}$ overnight. The schematic illustration of preparation process of nanostructured $\mathrm{Ag}_{3} \mathrm{PO}_{4}$ from natural phosphate is exhibited step by step in Scheme 1 .

Table 1. Khouribga natural phosphate analysis

\begin{tabular}{ccccccccc}
\hline Elements & $\mathrm{P}_{2} \mathrm{O}_{5}$ & $\mathrm{CaO}$ & $\mathrm{CO}_{2}$ & $\mathrm{SiO}_{2}$ & $\mathrm{~F}$ & $\mathrm{Al}_{2} \mathrm{O}_{3}$ & $\mathrm{SO}_{3}$ & $\mathrm{Fe}_{2} \mathrm{O}_{3}$ \\
\hline$(\%)$ & 30.74 & 50.47 & 6.64 & 5.91 & 3.60 & 0.43 & 1.83 & 0.2 \\
\hline
\end{tabular}


X-ray diffraction (XRD) patterns were obtained at room temperature on a Bruker AXS D-8 diffractometer using Cu-Ka radiation in Bragg-Brentano geometry $(\theta-2 \theta)$. Fourier transform infrared (FT-IR) was performed on an ABB Bomem FTLA 2000 spectrometer equipped with a Golden Gate single reflection ATR accessory. Scanning electron microscopy images were recorded on a FEI Quanta 200 microscope after carbon metallization. The TEM micrographs were obtained on a FEl microscope at $120 \mathrm{kV}$. Specific surface area was determined from the nitrogen adsorption/desorption isotherms (at- $196^{\circ} \mathrm{C}$ ) and measured with a Quantachrome Autosorb-1 automatic analyzer using the BET equation.

\subsection{Catalytic reduction of 4-nitrophénol to 4-aminophenol}

The catalytic activities were evaluated by reduction of 4-nitrophenol (4-NP) to 4-aminophenol (4-AP) in a quartz cuvette. In a typical procedure, $100 \mu \mathrm{L}$ of $4-\mathrm{NP}(1 \mathrm{mM})$ and $1 \mathrm{~mL} \mathrm{NaBH} \mathrm{N}_{4}(0.1 \mathrm{M})$ were placed in a quartz cuvette containing $3 \mathrm{~mL}$ of deionised water. After that $5 \mathrm{mg}$ of $\mathrm{Ag}_{3} \mathrm{PO}_{4}$ was added into the cuvette to start the reduction reaction. The process of the conversion of 4-NP to 4-AP was followed by UV-Vis spectroscopy at a maximum wavelength of $400 \mathrm{~nm}$.

\subsection{Antibacterial activity of nanostructured $\mathrm{Ag}_{3} \mathrm{PO}_{4}$ powder}

The antibacterial activity of the nanostructured $\mathrm{Ag}_{3} \mathrm{PO}_{4}$ was studied on Staphylococcus aureus (S. aureus) and Escherichia coli (E. coli) by the standard disk diffusion assay on Muller-Hinton agar medium. All disks and materials were sterilized in an autoclave at $120^{\circ} \mathrm{C}$ for $20 \mathrm{~min}$ before experiments. The disk diffusion assay was performed by placing a $6 \mathrm{~mm}$ disk saturated with $10 \mu \mathrm{L}$ of $\mathrm{Ag}_{3} \mathrm{PO}_{4}$ aqueous dispersions $(1000-125 \mu \mathrm{g} / \mathrm{mL})$ onto an agar plate seeded with E. coli or S. aureus. After 24 hours of incubation at $37^{\circ} \mathrm{C}$, the diameters of the inhibition zones were measured.

\section{Results And Discussion}

\subsection{Characterization of nanostructured $\mathrm{Ag}_{3} \mathrm{PO}_{4}$}

The phase structures of the as-prepared nanostructured $\mathrm{Ag}_{3} \mathrm{PO}_{4}$ were investigated by $\mathrm{XRD}$ and showed in Fig. 1.

X-ray diffraction patterns of nanostructured $\mathrm{Ag}_{3} \mathrm{PO}_{4}$ clearly showed that all diffraction peaks are a nearsystematic superposition of those of face-centered cubic structure of $\mathrm{Ag}_{3} \mathrm{PO}_{4}$ (JCPDS file $\mathrm{N}^{\circ}$ 010-1988). No diffraction peaks for other phases such as calcium phosphate are detected, this indicates that $\mathrm{Ag}^{+}$ cations have the best chemical affinity towards $\mathrm{PO}_{4}{ }^{3-}$ anions compared to that of $\mathrm{Ca}^{2+}$ ions originating from natural phosphate in which they have been cleaned from the solid by washing treatment. Without taking into account unreactive species $\left(\mathrm{Ca}^{2+}\right.$ and $\left.\mathrm{NO}^{3-}\right)$, the process of the reaction can be represented as follows: 


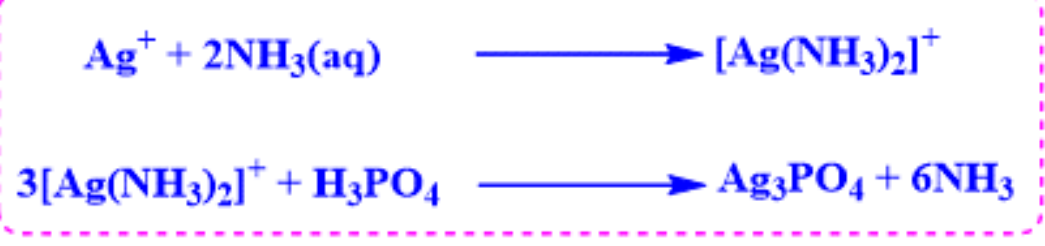

Furthermore, according to the Debye-Scherrer equation, the average crystallite size of the synthesized $\mathrm{Ag}_{3} \mathrm{PO}_{4}$ is about $39 \mathrm{~nm}$. A view of the structure along the [100] direction is shown in Fig.2. Hence, the polyhedron configuration of $\mathrm{Ag}_{3} \mathrm{PO}_{4}$ consists of tetrahedral $\mathrm{PO}_{4}$ and $\mathrm{AgO}_{4}$. It is obvious that one $\mathrm{PO}_{4}$ tetrahedron and three tetrahedral $\mathrm{AgO}_{4}$ are combined with each other through the corner oxygen. Additionally, the average of $\mathrm{P}-\mathrm{O}$ and $\mathrm{Ag}-\mathrm{O}$ distance is about $2.37 \AA$ and $1.54 \AA$, respectively.

Fig.3. showed the Fourier transform infrared (FT-IR) spectrum of the $\mathrm{Ag}_{3} \mathrm{PO}_{4}$ sample, exhibiting two strong bands in the $1072-732 \mathrm{~cm}^{-1}$ and $586-447 \mathrm{~cm}^{-1}$ ranges related to the molecular vibrations of $\mathrm{PO}_{4}$ groups in $\mathrm{Ag}_{3} \mathrm{PO}_{4}$ sample. The former band centered at $941 \mathrm{~cm}^{-1}$ with a very small shoulder at around $1056 \mathrm{~cm}^{-1}$ is assigned to the symmetric and asymmetric stretching mode of the P-O bonds, while the latter centered at $547 \mathrm{~cm}^{-1}$ is related to deformation from the bending mode of the $0-\mathrm{P}-\mathrm{O}$ bonds.

To better elucidate the morphology properties of the prepared $\mathrm{Ag}_{3} \mathrm{PO}_{4}$ from natural phosphate, SEM analysis was carried out. In the lower magnification images, the Fig.4a indicates that the surface of nanostructured $\mathrm{Ag}_{3} \mathrm{PO}_{4}$ is formed by a large amount of quasi-spheroid particles having hexagonal and cubic structures, while the higher magnification image, as shown in Fig.4b, clearly reveals the quasispheroid particles through non-uniform diameter polyhedrons. On the other hand, to confirm the chemical composition of the nanostructured $\mathrm{Ag}_{3} \mathrm{PO}$, a semi-quantitative elemental analysis was performed, and its EDS spectrum showed in Fig.4c. The obtained results revealed the presence of $\mathrm{O}, \mathrm{P}$ and $\mathrm{Ag}$ elements without any calcium traces indicating that the $\mathrm{Ag}_{3} \mathrm{PO}_{4}$ prepared is pure and does not contain any impurities. Note that the presence of carbon and copper peaks is originated from adhesive $\mathrm{Cu}$-carbon tape.

To further demonstrate the porous structure of nanostructured $\mathrm{Ag}_{3} \mathrm{PO}_{4}$, the specific surface area $\left(\mathrm{S}_{\mathrm{BET}}\right)$ of the $\mathrm{Ag}_{3} \mathrm{PO}_{4}$ powder was calculated from $\mathrm{N}_{2}$-sorption measurements and application of the BET method. As shown in Fig.5a, the sorption isotherm exhibited a type IV isotherm according to the IUPAC classification with a distinct hysteresis loop of $\mathrm{H} 3$. Its specific surface area was of $35 \mathrm{~m}^{2} / \mathrm{g}$ and average pore size $D_{p}$ calculated from BJH (Barrett-Joyner-Halenda) method was $3.1 \mathrm{~nm}$ and $7.3 \mathrm{~nm}$ (Fig.5b). Comparing with the low values given in the literature, a relatively large porous surface of $\mathrm{Ag}_{3} \mathrm{PO}_{4}$ catalyst could provide more active and beneficial sites for the adsorption of target molecules through the active sites of the catalyst, which would promote the catalytic reaction.

\subsection{Catalytic Reduction of 4-NP to 4-AP}


To investigate the catalytic activity of the $\mathrm{Ag}_{3} \mathrm{PO}_{4}$ as nanostructured catalyst, the reduction of 4nitrophenol to its corresponding amino derivatives, 4-aminophenol, in the presence of $\mathrm{NaBH}_{4}$ in aqueous media was chosen as a model reaction (Scheme 2). Currently, the reduction of 4-NP to 4-AP is monitored by UV-vis spectra at their specific wavelengths $317 \mathrm{~nm}$ for 4-NP and $300 \mathrm{~nm}$ for 4-AP.

Firstly, the ability of $\mathrm{NaBH}_{4}$ to reduce 4-NP in absence of our catalyst was examined. As shown in Fig. 6-A, the 4-NP in an aqueous solution has a maximum absorption at 317. After added $\mathrm{NaBH}_{4}$ into solution, the absorbance peak of 4-NP was red shifted from 317 to $400 \mathrm{~nm}$ immediately along with a colour change from light yellow to bright yellow. This peak was due to the formation of 4-nitrophenolate ions in alkaline condition caused by the addition of reducing agent, as supported elsewhere [22]. However, in the absence of our catalyst the thermodynamically favorable reduction of 4-nitrophenol was not watched and the absorbance peak corresponding to 4-nitrophenolate ions at $400 \mathrm{~nm}$ rest unchanged for a long time (Fig.6B). Then, when a small amount of $\mathrm{Ag}_{3} \mathrm{PO}_{4}$ nanostructured $(5 \mathrm{mg})$ was introduced into reaction solution, the absorbance peak at $400 \mathrm{~nm}$ decreases significantly within 32 min and concomitant appearance of a new peak at $300 \mathrm{~nm}$. The new absorption at $300 \mathrm{~nm}$ is characteristic peak of 4-AP, revealing the reduction of 4-NP to form 4-AP. In addition, as seen in the UV-Vis spectra (Fig.6.C), the presence of an isobestic point at $317 \mathrm{~nm}$ indicating that the catalytic reduction of 4-nitrophenol gives 4-aminophenol only without by product [23-24].

To understand the catalytic conversion kinetic of 4-NP, the pseudo-first-order model was used: $\ln \left(C_{t} / C_{0}\right)=$ $\ln \left(\mathrm{A}_{t} / \mathrm{A}_{0}\right)=-k_{a p p} t$, where $C_{0}$ and $C_{t}$ are the 4-NP concentrations at $\mathrm{t}=0$ and $\mathrm{t}=\mathrm{t}$, respectively and $k_{a p p}$ is the apparent rate constant, which is in good relationship with the disappearance of the nitrophenonlate band at $400 \mathrm{~nm}$ versus time. In this light, the influence of the $\mathrm{NaBH}_{4}$ molar concentration on the catalytic efficiency of the reduction of 4-NP into 4-AP was studied. Fig. 7a shows the $\ln \left(A_{t} / A_{0}\right)$ plot as a function of time at different concentration of reducing agent $(0.01 ; 0.05 ; 0.1$ and $0.5 \mathrm{M})$ at room temperature. Based on the results of this study, it is clearly seen that the constant rate conversion of 4-NP to 4-AP increases from $0.024 \mathrm{~min}^{-1}$ to $0.088 \mathrm{~min}^{-1}$ with increasing $\mathrm{NaBH}_{4}$ concentration from 0.01 to $0.5 \mathrm{M}$, respectively. These results can be interpreted by the presence of an excess of the reducing agent, which favouring the diffusion of $\mathrm{BH}_{4}{ }^{-}$ions on the catalyst surface by accelerating the reduction of the diffused 4-NP [2526]. Note that no significant change in apparent rate constant above $0.1 \mathrm{M}$ of $\left[\mathrm{NaBH}_{4}\right]$ was observed; thus, an optimum concentration of $0.1 \mathrm{M}\left[\mathrm{NaBH}_{4}\right]$ was chosen for the future experiments. In addition, the effect of amount of the $\mathrm{Ag}_{3} \mathrm{PO}_{4}$ nanostructured on catalytic efficiency was also studied using $0.1 \mathrm{M}$ of $\mathrm{NaBH}_{4}$ at room temperature. We should mentioned that the reaction was started after adding of $\mathrm{Ag}_{3} \mathrm{PO}_{4}$ as a nanostructured catalyst and the colour of the solution changed gradually from bright yellow to colourless indicated the successive reduction of 4-NP. As showed in Fig. 7b, the conversion reaction seems to be sensitive to the catalyst amount, but from $5 \mathrm{mg}$ of the catalyst, the reaction became uncontrollable and ends very quickly. Thus, the optimum amount of the catalyst was selected to be $5 \mathrm{mg}$. 
Based on the results described above the proposed mechanism for the reduction of 4-NP is given in schematic 3. As published elsewhere [27-29], the hydrogen atom of $\mathrm{BH}_{4}{ }^{-}$is positively charged and could create fine electrostatic attractions with negatively charged oxygen from nitro groups at catalyst surface, facilitating the removal of oxygen and reduction of nitro groups. In addition, the residual nitrogen of $-\mathrm{NO}_{2}$ is also negatively charged due to its greater electronegativity than carbon from the benzene ring, and the $\mathrm{H}$ atoms of the positively charged $\mathrm{H}_{2} \mathrm{O}$ molecules could easily combine with the residual nitrogen of the nitrophenol to form the final aminophenol product. Adding to the proton transfer and deoxygenation, electron transport must occur simultaneously from the $\mathrm{BH}_{4}{ }^{-}$clusters to 4-NP via the $\mathrm{Ag}_{3} \mathrm{PO}_{4}$ catalyst substrate to compensate for the charge balance and accomplish the process of reduction.

The reusability of the catalyst is another important factor from economic and environmental point of view, which it is highly desirable to examine in this study. At the end of the reaction, the catalyst was easily separated by filtration from solution, washed with deionized water and ethanol, dried at $80^{\circ} \mathrm{C}$ and then was reused for the next cycle of catalysis. As shown in Fig. 8, the catalyst was recycled several times with a little loss in catalytic performance after the third cycle. This can be explained by the reduction of silver $\left(\mathrm{Ag}^{+} \rightarrow \mathrm{Ag}^{0}\right)$ by the excited electrons during catalytic processes, confirmed by the gradual colour change of the $\mathrm{Ag}_{3} \mathrm{PO}_{4}$ catalyst (From yellow to dark brown), resulting in decrease in the catalytic efficiency.

\subsection{Antibacterial activity studies}

The production of a large quantity of $\mathrm{Ag}_{3} \mathrm{PO}_{4}$ through a simple and economical method from natural phosphate can be employed as antibacterial agent suitable for the biological treatment of wastewater. In this optic, the obtained results of antibacterial activity of $\mathrm{Ag}_{3} \mathrm{PO}_{4}$ against $\mathrm{E}$. Coli (Gram-negative) and $\mathrm{S}$. Aureus (Gram-positive) are shown in Fig. 9. The zone of inhibition clearly indicated the significant antibacterial effect of the nanostructured $\mathrm{Ag}_{3} \mathrm{PO}_{4}$ as quantitatively shown in Table 2. With $1 \mathrm{mg} / \mathrm{mL}$ as the serial concentration of $\mathrm{Ag}_{3} \mathrm{PO}_{4}$ in the biological solution, the maximum diameters of the zones of inhibition are approximately $12.01 \mathrm{~mm}$ and $13.50 \mathrm{~mm}$ against $\mathrm{S}$. aureus and $\mathrm{E}$. coli, respectively. As result, the nanostructured powder of $\mathrm{Ag}_{3} \mathrm{PO}_{4}$ prepared from phosphate rock is in fact an effective antibacterial agent on Gram positive and Gram-negative bacteria such as largely described in the literature.

Table 2. The inhibition diameter zone of the nanostructured $\mathrm{Ag}_{3} \mathrm{PO}_{4}$ against $E$. Coli and $S$. Aureus at different concentrations.

\begin{tabular}{ccc}
\hline $\begin{array}{c}\text { Concentration } \\
\text { (mg/mL) }\end{array}$ & $\begin{array}{c}\text { Zone of inhibition (mm) } \\
\text { E. coli }\end{array}$ & S. Aureus \\
\hline 1 & 13.50 & 12.01 \\
0.5 & 12.54 & 11.33 \\
0.25 & 10.20 & 10.9 \\
0.125 & 10.00 & 9.2 \\
\hline
\end{tabular}




\section{Conclusion}

This study develops a novel approach for the synthesis of the single phase of the nanostructured $\mathrm{Ag}_{3} \mathrm{PO}_{4}$ from natural phosphate as phosphate source via dissolution-precipitation process. The as-prepared sample was successfully characterized by various physicochemical techniques in order to study its thermal, structural, textural and morphological properties. Then, the nanostructured catalyst exhibited higher catalytic activity towards the reduction of 4-nitrophenol to 4-aminophenol using $\mathrm{NaBH}_{4}$ as reducing agent in aqueous solution. In addition, the prepared $\mathrm{Ag}_{3} \mathrm{PO}_{4}$ catalyst possesses significant antibacterial activities against E. Coli and S. Aureus bacteria. The operational simplicity, short reaction times, recyclability and antibacterial activity are the outstanding features of the present study.

\section{Declarations}

Funding: The authors would like to thank the Moroccan Foundation for Advanced Science, Innovation and Research (MAScIR) for its financial support (allowance) particularly for giving us the opportunity to have access to its fully sophisticated technological platform to perform this work and to characterize our materials.

Competing interests: The authors declare that they have no competing interests.

Availability of data and materials: All data generated or analysed during this study are included in this published article.

\section{References}

1. M.R. Hoffmann, S.T. Martin, W. Choi, D. W. Bahnemann., Chem. Rev. 95, 69 (1995)

2. C. Chen, W. Ma, J. Zhao. Chem. Soc. Rev. 39, 4206 (2010)

3. F.K. Higson, Adv. Appl. Microbiol. 37, 1 (1992)

4. I. Rodriguez, M.P. Llompart, R. Cela. J. Chromatogr. 885, 291 (2000)

5. J. Feng, L. Su, Y. Ma, C. Ren, Q. Guo, X. Chen., Chem. Eng. J. 221, 16 (2013)

6. T. Komatsu, T. Hirose, Appl. Catal., A. 276, 95 (2004)

7. C.V. Rode, M.J. Vaidya, R. Jaganathan, R.V. Chaudhari, Chem. Eng. Sci. 56, 1299 (2001)

8. M.J. Vaidya, S.M. Kulkami, R.V. Chaudhari, Org. Process Res. Dev. 7, 202 (2003)

9. Q. Liang, W. Ma, Y. Shi, Z. Li, X. Yang, Cryst. Eng. Comm. 14, 966 (2012)

10. A. Khan, M. Qamar, M. Muneer. Chem. Phys. Lett. 519, 54 (2012)

11. Y. Bi, H. Hu, S. Ouyang, G. Lu, J. Caob, J. Ye. Chem. Commun. 48, 3748 (2012)

12. W.G. Wang, B. Cheng, J.G. Yu, G. Liu, W.H. Fan, Chem. Asian. J. 7, 1902 (2012)

13. M. Zahouily, M. Salah, B. Bahlaouane, A. Rayadh, A. Houmam, E.A. Hamedb, S. Sebti., Tetrahedron 60, 1631 (2004) 
14. M. Zahouily, A. Mezdar, J. Rakik, A. Elmakssoudi, A. Rayadh, Said Sebti., J. Mol. Catal A-Chem. 233, $43(2005)$

15. M. Zahouily, A. Elmakssoudi, A. Mezdar, A. Rayadh, S. Sebti., Catal Commun. 8, 225 (2007)

16. K. Dânoun, I. Jioui, M. Bouhrara, M. Zahouily, A. Solhy, M. Jouiad, C. Len, A. Fihri, Curr. Org. Chem. 19, $2132(2015)$

17. I. Jioui, K. Dânoun, A. Solhy, M. Jouiad, M. Zahouily, B. Essaid, C. Len, A. Fihri, J. Ind. Eng. Chem 39, $218(2016)$

18. K. Dânoun, Y. Essamlali, O. Amadine, R. Tabit, A. Fihri, C. Len, M. Zahouily. Appl. Organomet. Chem. 32, 1 (2018)

19. R. Tabit, O. Amadine, Y. Essamlali, K. Dânoun, A. Rhihil, M. Zahouily. RSC Adv. 8, 1351 (2018)

20. A. Amedlous, O. Amadine, Y. Essamlali, K. Dânoun, M. Aadilb Mohamed Zahouily. RSC Adv. 9, 14132 (2019)

21. Y. Karim Dânoun, Essamlali, Othmane Amadine, Hassan Mahi and Mohamed Zahouily. BMC Chemistry 14, 2 (2020)

22. S. Jana, S.K. Ghosh, S. Nath, S. Pande, S. Praharaj, S. Panigrahi, S. Basu, T. Endo, T. Pal, Appl Catal: A-Gen. 313, 41 (2006)

23. S.K. Ghosh, M. Mandal, S. Kundu, S. Nath, T. Pa, Appl Catal A: Gen. 268, 61 (2004)

24. Y. Deng, Y. Cai, Z. Sun, J. Liu, C. Liu, J. Wei, W. Li, Y. Wang, D. Zhao, J. Am. Chem. Soc. 132, 8466 (2010)

25. Y. Zhang, G. Gao, Q. Qian, D. Cui, Nanoscale Res Lett 7, 2 (2012)

26. H. Koga, Y. Umemura, T. Kitaoka, Catalysis 1, 69 (2011)

27. K. Layek, M.L. Kantam, M. Shirai, D. Ni-Hamane, T. Sasaki, H. Maheswaran, Green Chem. 14, 3164 (2012)

28. P. Zhang, Ch Shao, Zh Zhang, M. Zhang, J. Mu, Z. Guoab, Y. Liua, Nanoscale 3, 3357 (2011)

29. R. Bendi, T. Imae, RSC Adv. 3, 16279 (2013)

\section{Figures}




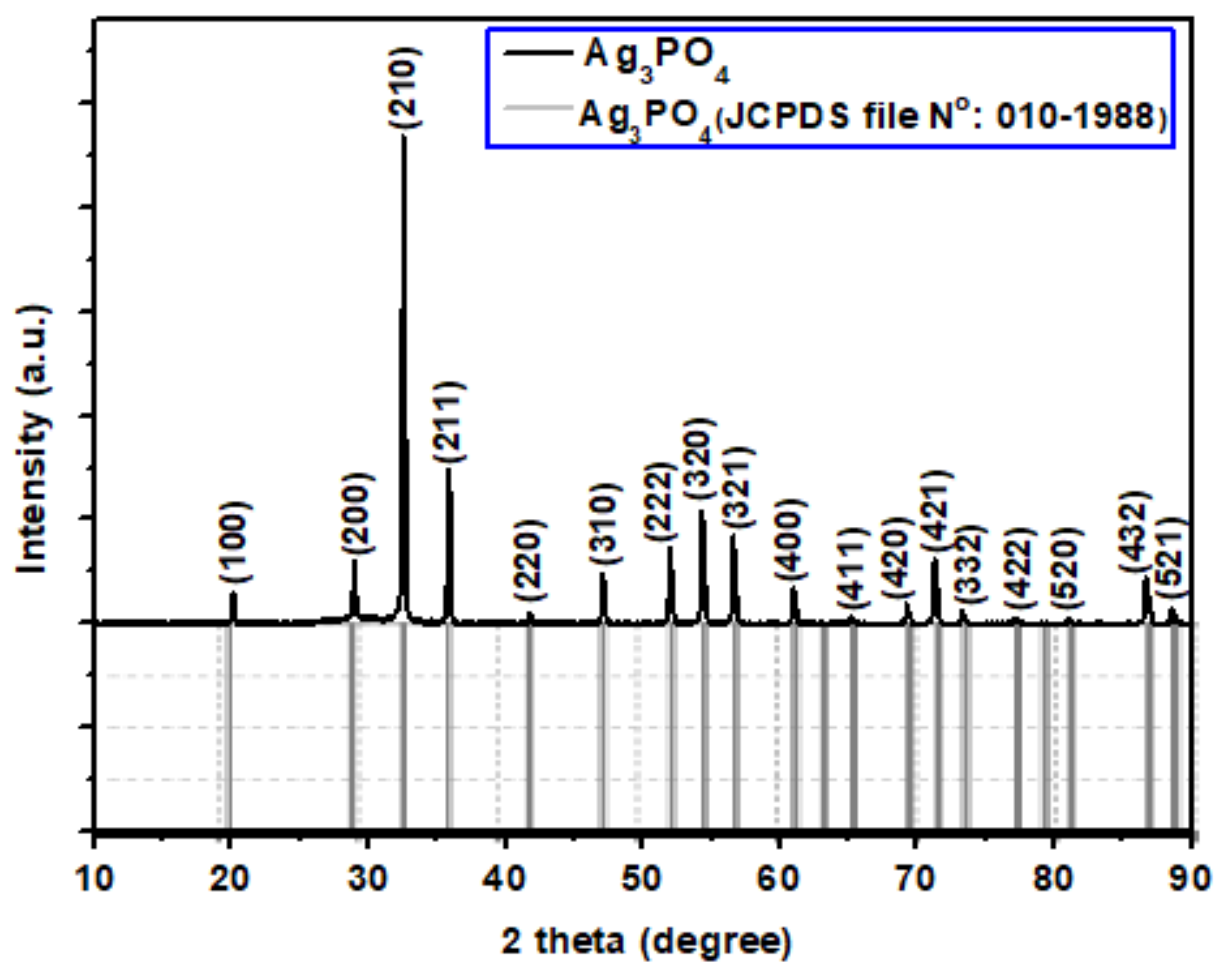

Figure 1

X-ray diffraction pattern of nanostructured Ag3P04.

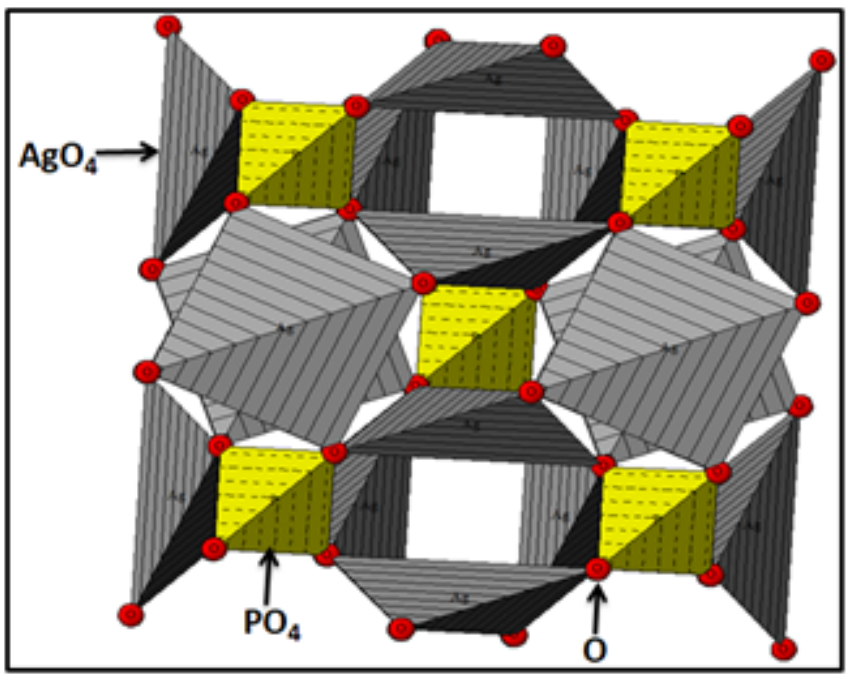

Figure 2

Projection view of nanostructured Ag3P04along [100] direction. 


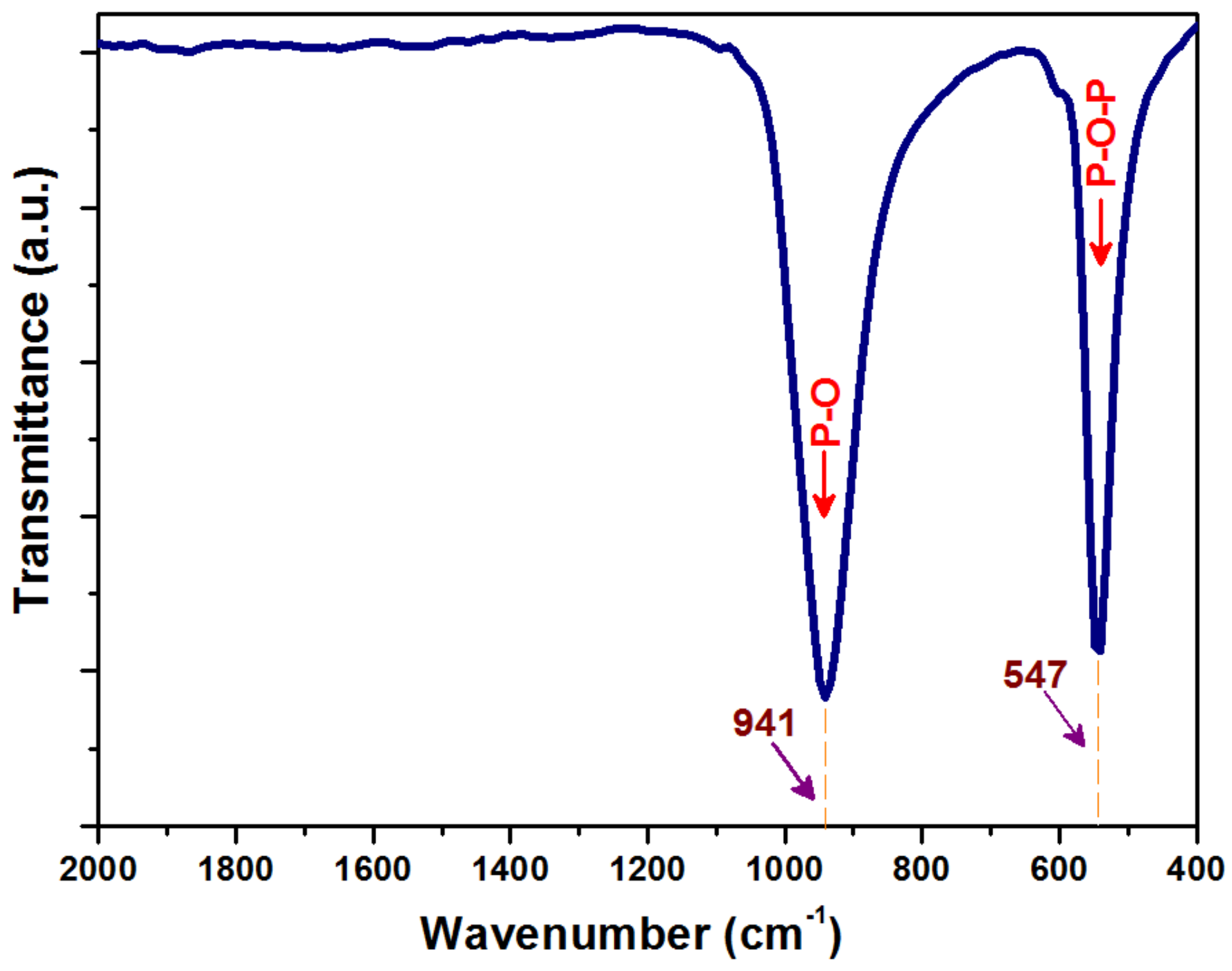

Figure 3

FT-IR spectra of nanostructured Ag3P04 powder. 


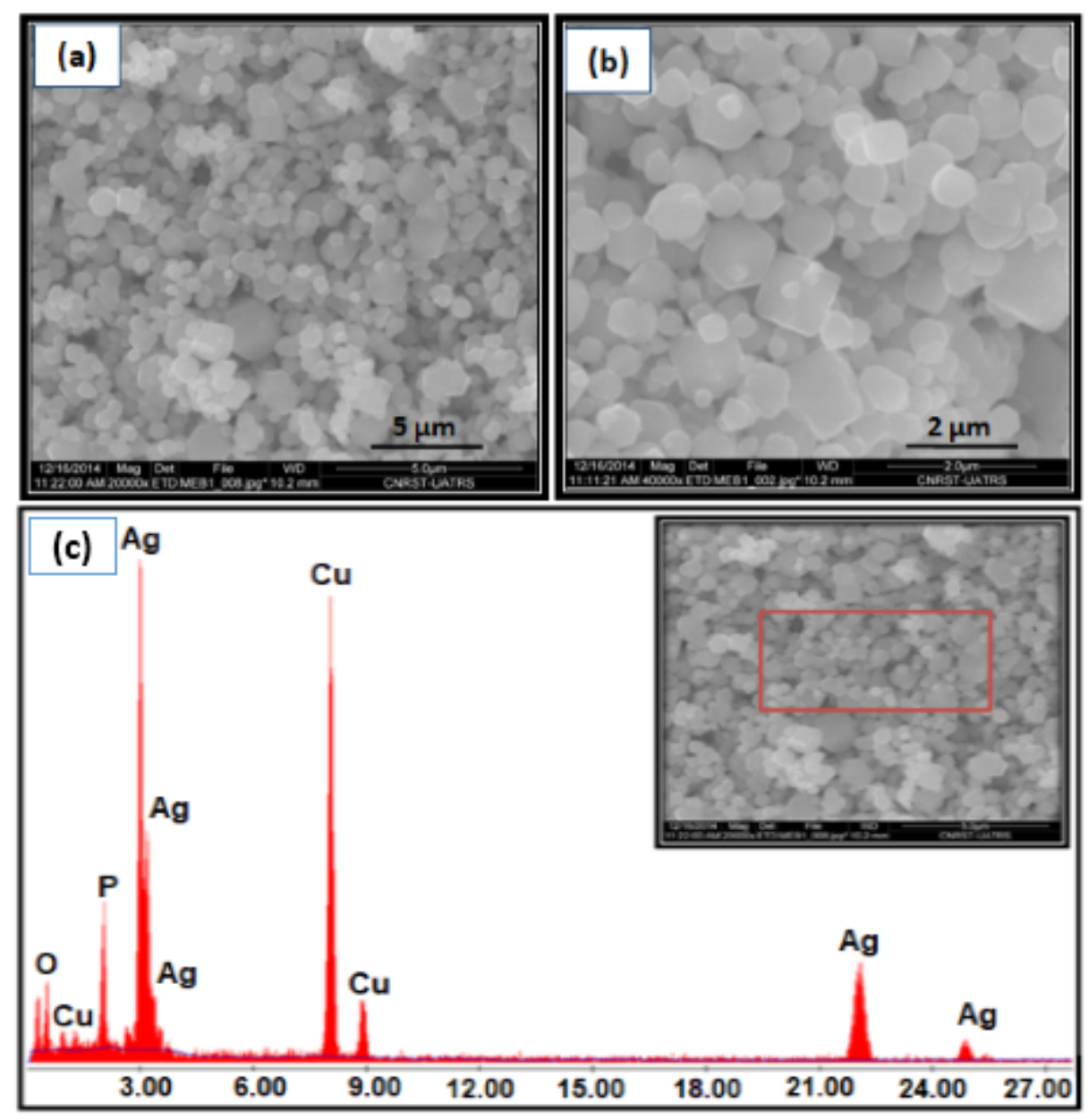

Figure 4

(a and b) SEM images and (c) EDS spectrum of the prepared Ag3PO4 powder 

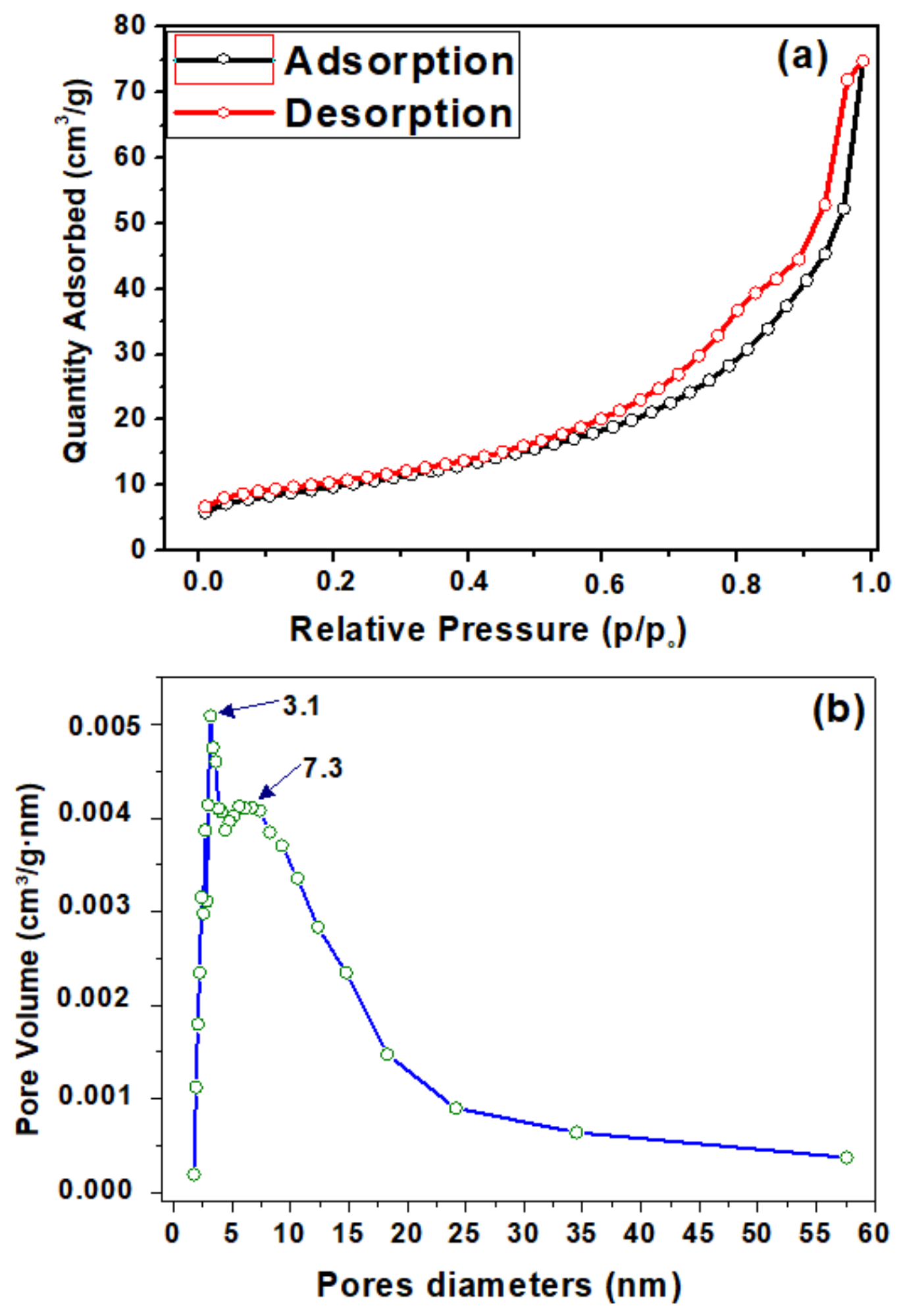

Figure 5

(a) N2-sorption isotherms and (b) BJH pore size distribution of Ag3PO4 prepared form NP. 

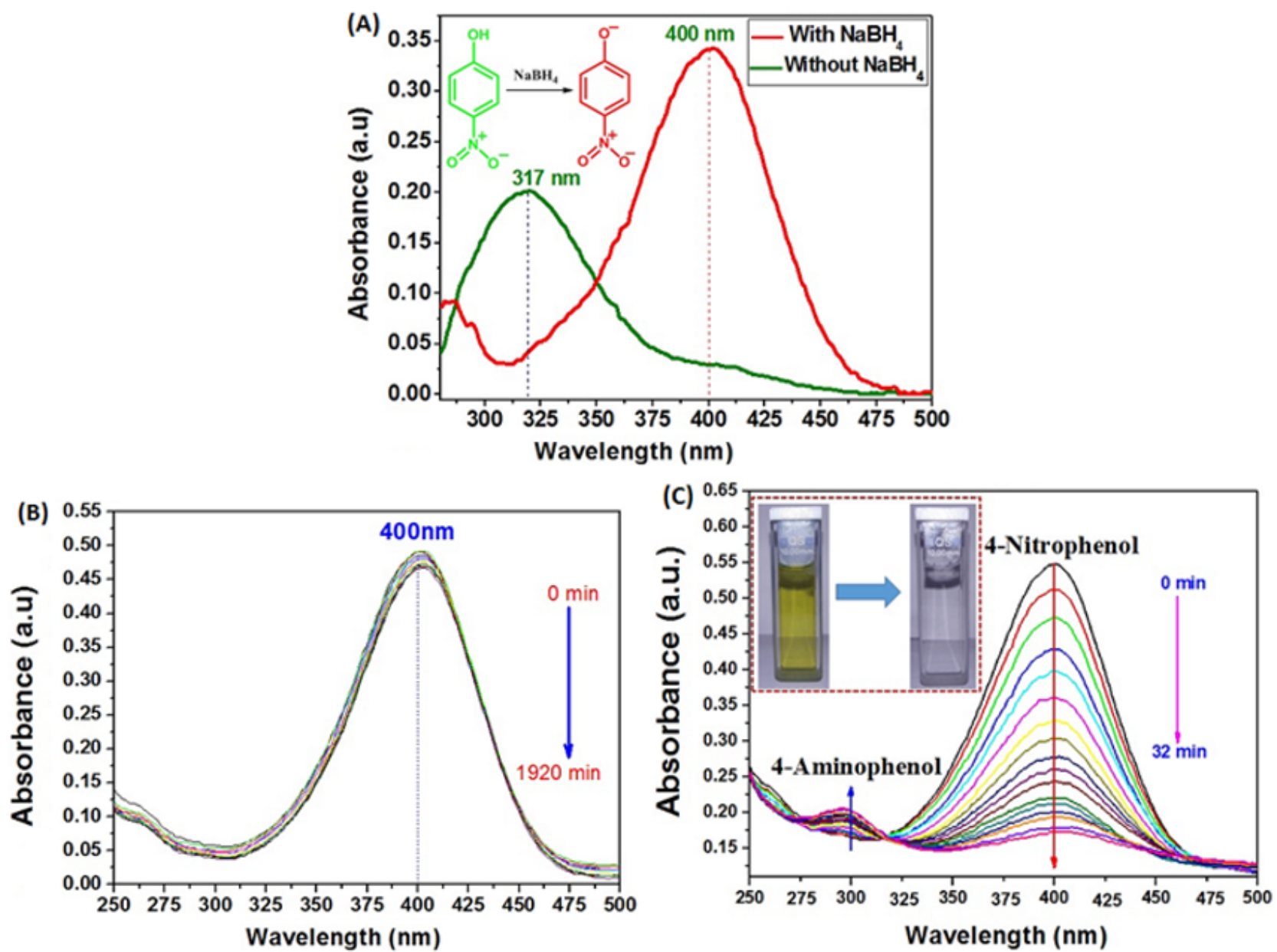

Figure 6

(a) UV-vis spectra of aqueous solutions of 4-NP with and without NaBH4, (b) UV-vis spectral evolution of solutions of 4-NP in the presence of $\mathrm{NaBH} 4$ without catalyst, (c) in the presence of nanostructured Ag3PO4 catalyst. 

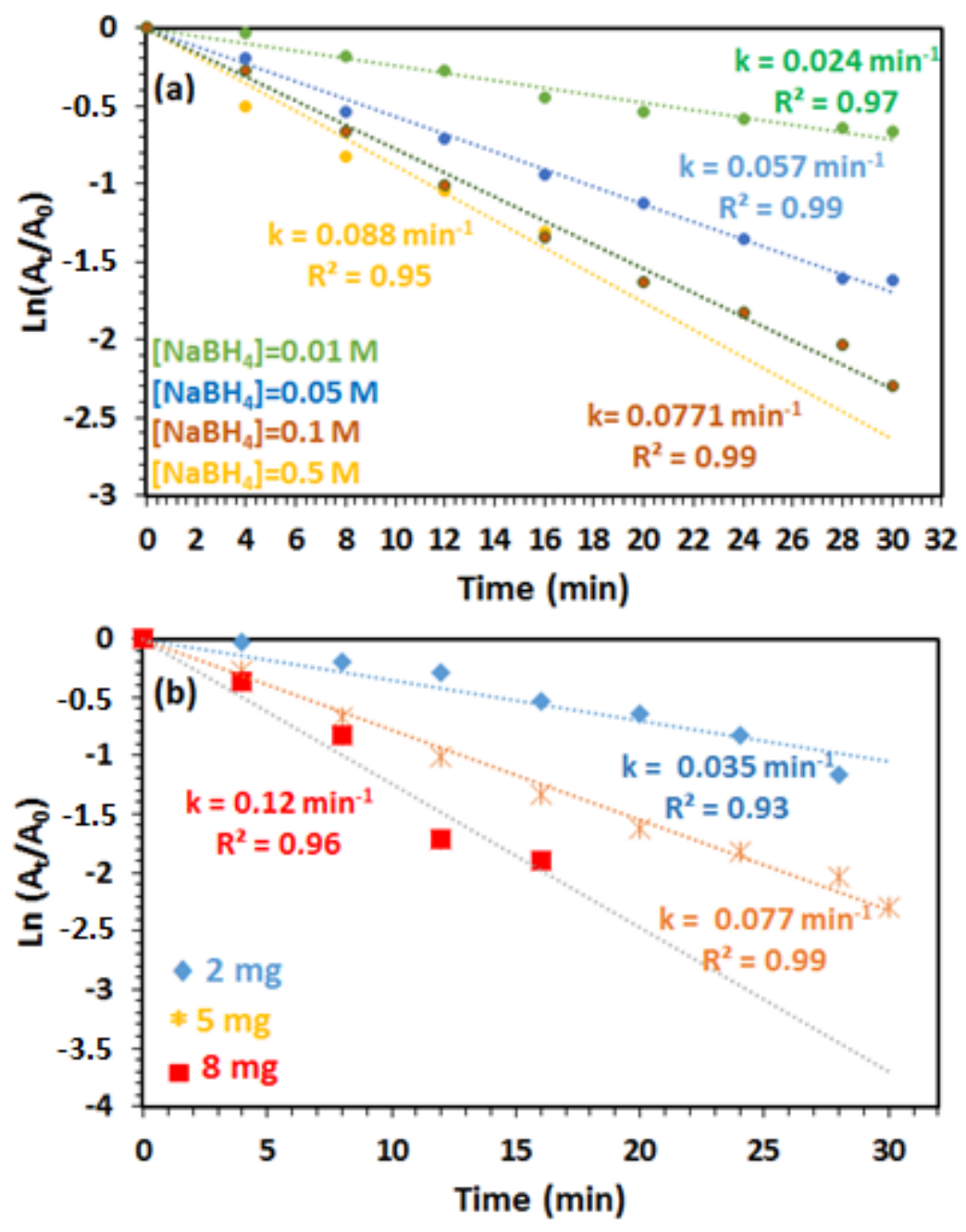

Figure 7

Logarithm of the absorbance at $400 \mathrm{~nm}$ versus reduction time of 4-NP under different conditions: (a) [NaBH4] molar concentration (b), and amount of catalyst.

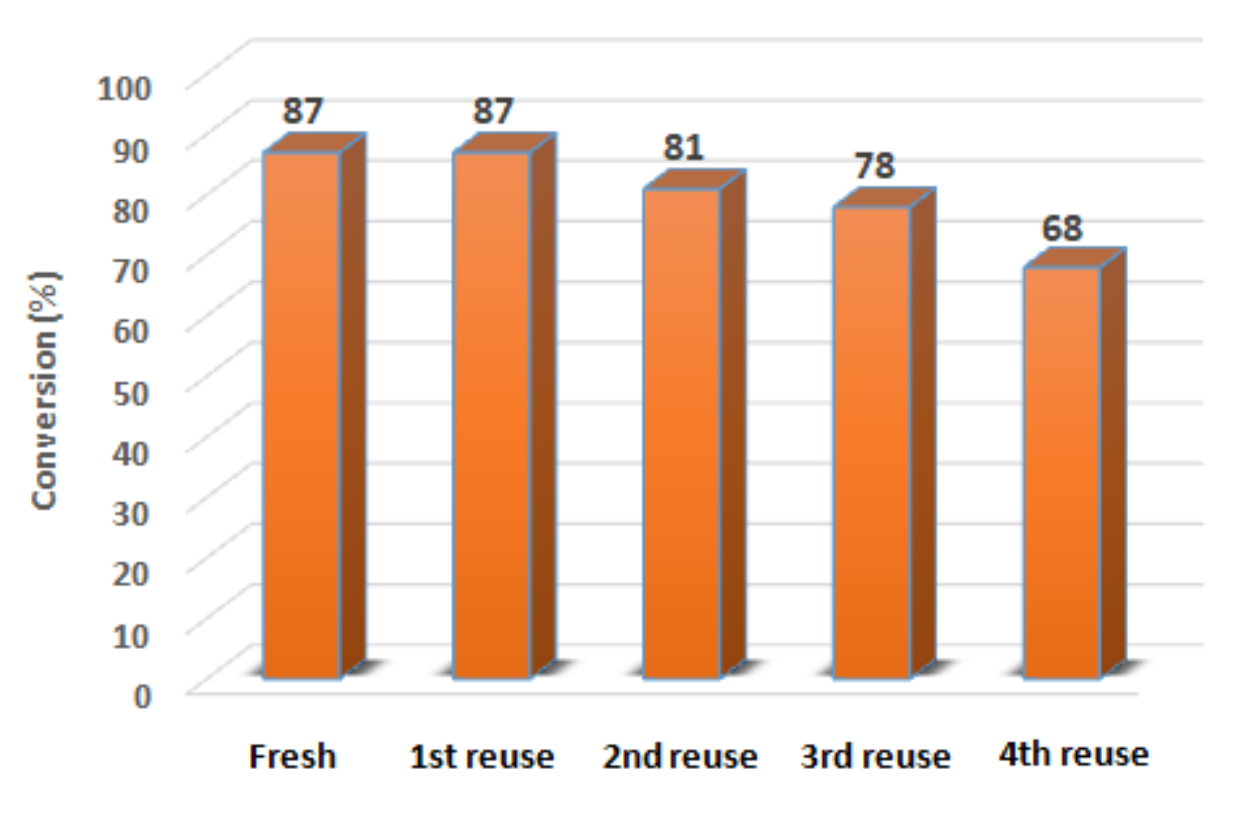


Figure 8

Reuse performance of nanostructured Ag3PO4 catalyst in reduction of 4-nitrophenol to 4-aminophenol.
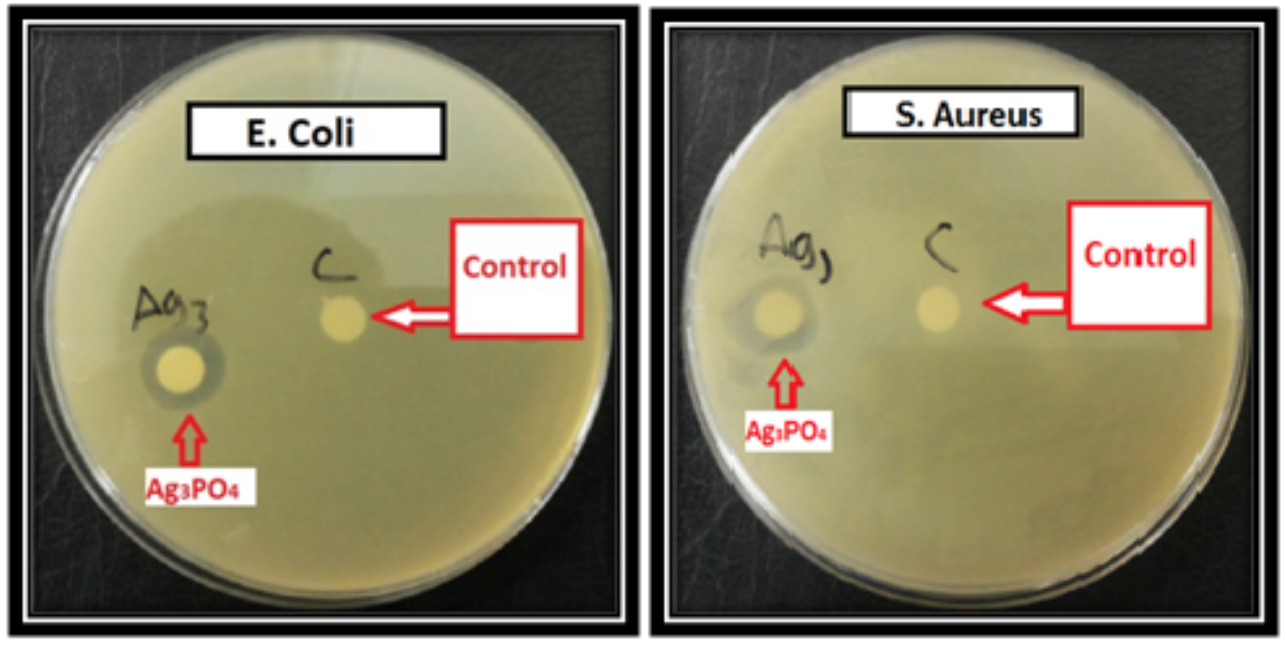

Figure 9

Antibacterial test results for E. Coli and S. Aureus after 24 hours of incubation using nanostructured Ag3PO4 $(1 \mathrm{mg} / \mathrm{mL})$.

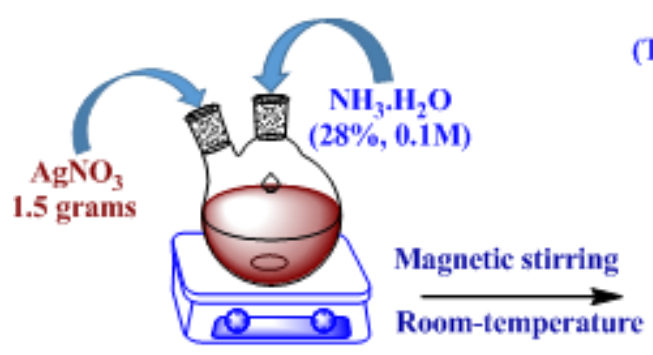

Formation of silver-amino complex $\left[\mathrm{Ag}\left(\mathrm{NH}_{3}\right)_{2}\right] \mathrm{NO}_{3}$ (Transparent solution)
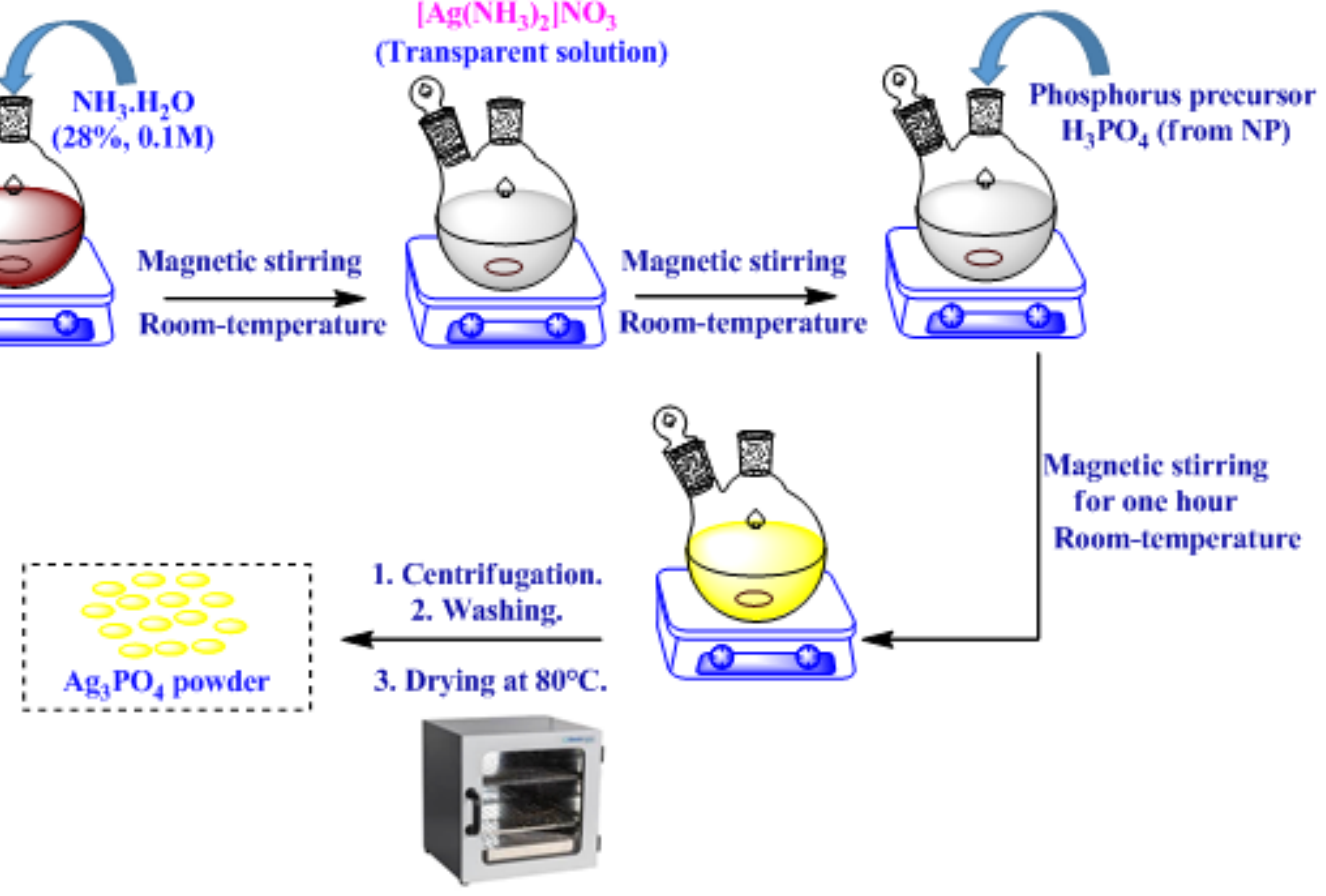

Figure 10

Scheme 1. Schematic diagram of the preparation of nanostructured Ag3PO4 by dissolution-precipitation process from natural phosphate. 


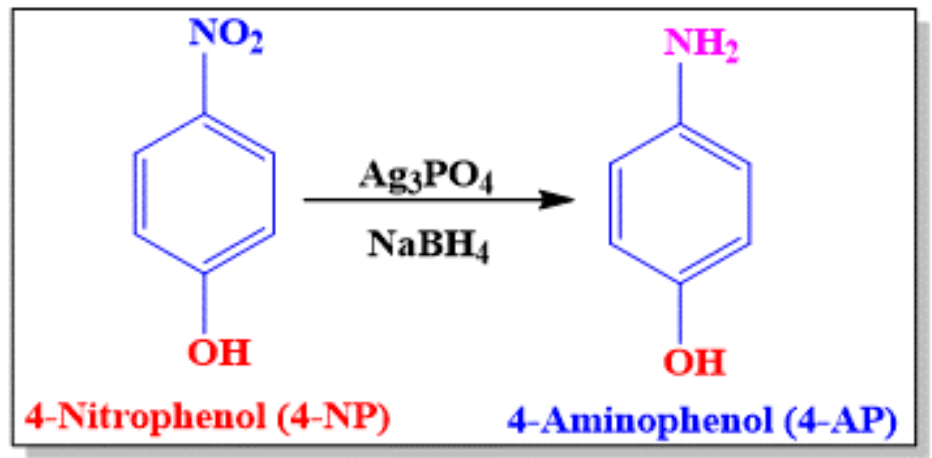

Figure 11

Scheme 2. Representation of the overall reaction process for converting 4-NP to 4-AP by $\mathrm{NaBH} 4$ in the presence of nanostructured Ag3PO4 powder.

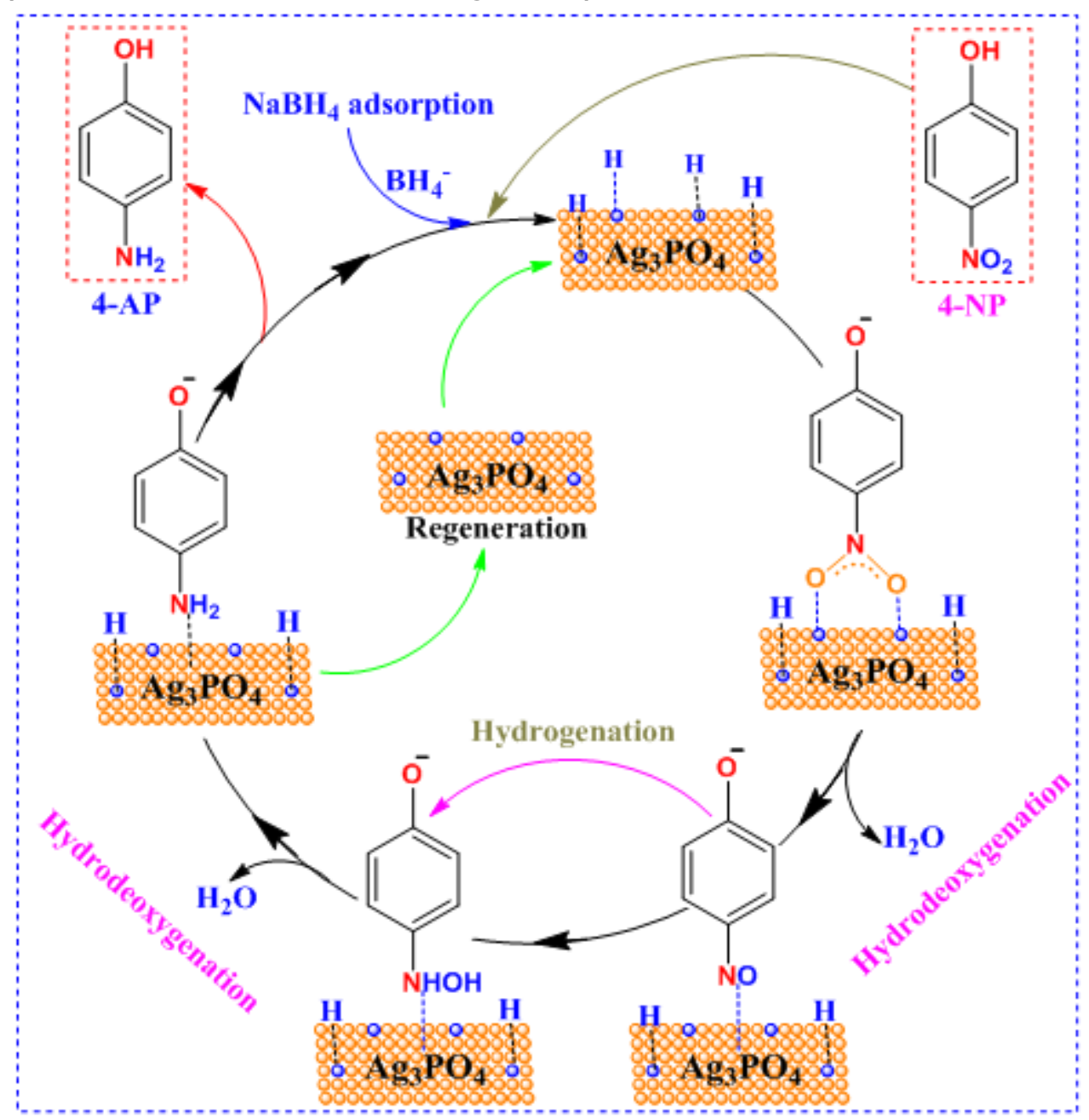

Figure 12

Schema 3. Mechanism for the reduction of 4-NP by the NaBH4 with nanostructured Ag3PO4 catalyst.

\section{Supplementary Files}


This is a list of supplementary files associated with this preprint. Click to download.

- floatimage16.png 